\title{
Hrvatski katolički pokret na početku 20. stoljeća
}

Ivan Zubac*

\begin{abstract}
Sažetak
U članku je pružen pregled nastanka i razvoja organizacija Hrvatskog katoličkog pokreta i Katoličke akcije, jednog od najznačajnih događaja Crkve u Hrvata na početku 20. stoljeća. Članak je podijeljen na tri dijela koji korespondiraju s najvažnijim zbivanjima unutar tog razdoblja. To su stvaranje nove južnoslavenske države, razdoblje pseudoparlamentarizma u 20-im godinama prošlog stoljeća te posljednje desetljeće života Kraljevine SHS/Kraljevine Jugoslavije.

Ključne riječi: Hrvatski katolički pokret, Katolička akcija, Hrvatski orlovski savez, Kraljevina SHS/Kraljevina Jugoslavija
\end{abstract}

\section{Uvod}

U ovom članku kroz tri tematske cjeline predočena je povijest i razvoj Hrvatskog katoličkog pokreta (HKP) i Katoličke akcije (KA) u prvim desetljećima 20. stoljeća (1900.-1945.). Prvi dio obuhvaća period od Prvog hrvatskog katoličkog sastanka 1900. (Korenić, 1900) ${ }^{1}$ do kraja Prvog svjetskog rata 1918. godine. Prikazane su bitne tendencije i fenomeni, čije su se posljedice očitovale i u vremenu nakon stvaranja prve zajedničke države Južnih Slavena.

Drugi dio obuhvaća period od 1918. do proglašenja Šestosiječanjske diktature 1929. (Znidarčić, 2002). Ubrzo nakon sudbonosnog 1. prosinca 1918., tj. stvaranja prve južnoslavenske države, državna vlast prilično je nedvosmisleno pokazala što misli o hrvatskom narodu i Katoličkoj crkvi. Sredinom 20-ih godina došlo je do prvih koncepcijskih razilaženja unutar HKP-a u promišljanjima o tome kakva bi uloga Crkve u društvu trebala biti.

Treći dio govori o razdoblju od 1929. do izbijanja Drugog svjetskog rata u travnju 1941. godine. Neposredno nakon uvođenja diktature Kraljevina Jugoslavija postala je totalitarna država koja u pravni sustav uvodi verbalni delikt i "zločin protiv države". Mnogi prvaci hrvatskog naroda, kao i HKP-a našli su se

* Ivan Zubac, doktorand na Fakultetu za povijest i kulturna dobra Crkve, Papinsko sveučilište Gregoriana, Piazza della Pilotta, 4, 00187 Roma, Italia. E-pošta: ivanzubac@gmail.com

1 Autor donosi prikaz svih sjednica i tematskih cjelina koje su prvaci Crkve u Hrvata (kako kler tako i laikat) tadašnjeg doba obrađivali. 
na udaru represivnog aparata. Pred kraj 30-ih uspostavljen je svojevrsni detant, kako unutar raznih organizacija HKP-a, tako i u odnosima Katoličke crkve s državom.

Određeni je naglasak stavljen na neobjavljeno arhivsko gradivo. Jedan od ciljeva rada na izvornim povijesnim vrelima bio je i pokušaj pronalaska dokumenta koji bacaju novo svjetlo i perspektive na razvoj HKP-a i KA u Crkvi u Hrvata, te aktivnosti nekih od glavnih protagonista.

\section{Prvo razdoblje (1900.-1918.)}

Hrvatski se narod u osvitu 20. stoljeća nalazio u nezavidnoj situaciji. Podijeljenost se očitovala na svim područjima. Politički, Hrvati su živjeli u AustroUgarskoj Monarhiji, no u različitim administrativnim cjelinama (Bilandžić, 1999, 18). Hrvatska i Slavonija bile su pod ingerencijom Budimpešte, Istra i Dalmacija pod upravom Beča, a Bosna i Hercegovina bila je svojevrsni pravni corpus separatum. Ekonomski hrvatski narod nije uspio puno profitirati od europskog proljeća naroda iz 1848. godine (Suppan, 1980). ${ }^{2}$ Iste godine ban Jelačić ukinuo je kmetstvo, no 1900. velik broj stanovništva još je uvijek pripadao seljačkomu staležu.

Pitanje braka ${ }^{3}$ (posebice mješovitih), vjerske pripadnosti i školskog sustava ${ }^{4}$ bili su aktualni već od sredine 19. stoljeća i o njima su promišljali protagonisti Hrvatskog katoličkog pokreta u njegovim početcima.

Zvijezda na licu Kristove Crkve u Hrvata u tom je vremenu bez sumnje bio tadašnji Đakovački biskup Josip Juraj Strossmayer. Od mnogobrojnih aspekata i aktivnosti koje je biskup Strossmayer vodio spomenut ću dvije, čije su posljedice bile vidljive i nakon stvaranja Kraljevine Srba, Hrvata i Slovenaca.

Prva je bila pitanje slavenskog jezika u liturgiji, tj. glagoljice, što su austrijski i mađarski krugovi smatrali kao prijetnju poretku same države i potencijalnu opasnost u smislu približavanja katoličkog stanovništva pravoslavlju. Neposredno s tim u vezi su ekumenska nastojanja biskupa Strossmayera, tj. približavanje Srpskoj pravoslavnoj crkvi. ${ }^{5}$ Druga je držanje bečkog Dvora prema rješenju hrvatskog nacionalnog pitanja i nepopustljivošću prema uvažavanju legitimnih hrvat-

2 U odlomku Zur sozialen Lage der kroatischen Bauern autor daje precizan i detaljan presjek stanja hrvatskog seljaštva iz kojega se može iščitati presjek gospodarstva u cjelini.

3 Usp. AT-OeStA/AVA Kultus NK Kath Akten. 7.5. Signatur 10: Militärehen, Aufgebote, Zivilehen, Ungarn und für alle Länder: Ehen nach Nachnamen - D. Dopis ministarstva pravde i vjera br. 2160 iz 1882. drugim državnim tijelima. U tom dokumentu, izdanom od strane Ministerium für Kultus und Unterricht (Ministarstvo vjera), na precizan se način definiraju pitanja kanonske jurisdikcije, pitanja crkvenog braka i matica, pa čak i procedura za dobivanje državljanstva.

4 Usp. AT-OeStA/AVA Kultus NK Kath Akten 79.22. Signatur 27: Unterricht der katholischen Jugend im Allgemeinen. Dokument br. 9342 iz 1858. Govori o nekim aspektima mađarskog dijela Monarhije (Schulconcurrenz in Ungarn), točnije u Sigetu, opisuje se način biranja kandidata u škole i program koji će isti morati svladati. Za nas je posebice bitan zbog činjenice da je pravna legislativa u ugarskom dijelu Monarhije bila važeća i za tadašnji teritorij Hrvatske.

5 Usp. HR-HDA-71. Carsko kraljevsko Ministarstvo bogoštovlja i nastave. Hrvatsko-slavonski spisi. 1848-1861; 2. Bosanska ili Đakovačka biskupija 1849-1859; spis br. 2598. Službeno obraća- 
skih interesa. Biskup Strossmayer proročki je navijestio kakvu je grešku Austrija radila u tom pitanju. ${ }^{6}$ Beč je Đakovačkog biskupa dosta često apostrofirao kao nositelja hrvatskog nacionalizma. ${ }^{7}$

Hrvatski se narod izbijanjem Prvog svjetskog rata našao u jako teškom položaju. Bilo kakav ishod, pobjeda Centralnih sila ili Antante u sebi je nosila potencijalne opasnosti. Ta dilema zaokupljala je pozornost većine protagonista HKPa. Nakon nekog vremena iskristalizirala se opcija da bi pobjeda Centralnih sila imala bitno gore posljedice za rješenje hrvatskog nacionalnog pitanja. Smatralo se da bi pobjeda Monarhije i njezinih saveznika u konačnici rezultirala još većom centralizacijom koja bi Hrvatsku vratila u doba Bachova apsolutizma.

Najprihvatljivije rješenje za većinu intelektualaca Crkve u Hrvata bila je pobjeda Antante, raspad Monarhije i unija s ostalim južnoslavenskim narodima, prvenstveno sa Slovencima i Srbima. U trenutku raspada četiri velika carstva, otvorene talijanske težnje za hrvatskim Jadranom i mogućnosti talijansko-srpske suradnje, unija s ostalim Južnim Slavenima činila se kao najmanje loše rješenje. Ne bismo trebali upadati u povijesne anakronizme te s ove vremenske distance i našeg povijesnog iskustva s Jugoslavijom suditi odluke koje su ljudi ondašnjeg vremena donijeli (Boban, 2001). ${ }^{8}$

Krčki biskup Mahnić bio je jedan od onih protagonista koji su usmjerili hrvatski put prema prihvaćanju Svibanjske i Krfske deklaracije (Radić, 1940). Biskup Mahnić bio je ideolog i pokretač strujanja koja su rezultirala stvaranjem mnogobrojnih udruga, pokreta, tiskovina i pravim procvatom organiziranog djelovanja hrvatskih katoličkih laika. Spomenimo samo prvo akademsko društvo Hrvatska osnovano u Beču 1903., list Luč pokrenut 1905. ili osnivanje Hrvatskog katolič-

nje Svetoj Stolici u kojem se traži da se odobri imenovanje biskupa Strossmayera za administratora svih katolika u Srbiji (kut. 148).

6 Usp. AT-Oesta/HHStA PA XI 260. V/5: Slavische Liturgie (1887-1890). Politička korespondencija br. 34 s nadnevkom 26. rujna 1888. Riječ je o izvatku iz katoličkih novina Pall Mall Gazette iz Londona, članak o biskupu Strossmayeru naslovljen $A$ Prince-Bishop from the East. Članak je bogat informacijama o biskupovim kontaktima s poznatim društvenim akterima u Europi toga vremena (Gladstone, Minghetti). U jednom od odgovora novinaru tog lista biskup Strossmayer odgovora na optužbe da će približavanje Srpskoj pavoslavnoj crkvi i pravoslavlju katolike odvesti čak pod skute Rusije: »For our dear old Austria I would give my life at once. It is in her bosom that we Western Slavs ought to live and grow and attain our destiny. [...] It is impossible to take away language and nationality, from a numerous race, occupying extensive contiguous territories, where there is room for thirty of forty millions of people. Those who would attempt it, or would arrest our legitimate development, are the only ones who work for Russia«.

7 Beč je smatrao da Strossmayer utječe na druge hrvatske biskupe da se zalažu za stavove slične njegovim, koji su smatrani da odražavaju hrvatski nacionalizam: »Nuntius Taliani befürchtete bei dieser Gelegenheit einen neuen Ausbruch des kroatischen Nationalismus: Il Croatismo camina innanzi al Cattolicismo, meinte er und sah die zentrale Rolle Strossmayers« (Gottsmann, 2010, 99).

8 Mora se priznati da je to delikatno razdoblje kraja Prvog svjetskog rata još uvijek nedovoljno istraženo i da je bilo puno sila koje su imale svoje interese. Od Tomaša Masaryka i češke masonerije do geopolitičkih interesa Velike Britanije. Jedan od najvažnijih engleskih političara tog vremena Robert William Seton-Watson par puta je napomenuo da Britanija nije mogla dopustiti dominaciju ni jedne države na jugoistoku Europe. Rusija je čak upozoravala vladu Kraljevine Srbije da ni u kojem slučaju ne pravi zajedničku državu sa tolikim brojem katolika. 
kog akademskog društva Domagoj 1906. (Krišto, 2004, 48). Jedna od najbitnijih poluga u toj "razdiobi duhova", 9 tj. sudaru liberalne i katoličke misli, pripala je Hrvatskomu katoličkomu senioratu osnovanomu 1913., koji je odigrao temeljnu ulogu u povezivanju hrvatskih snaga neposredno prije i u obnovi istih poslije rata. Seniorat su činile osobe sa završenim visokim obrazovanjem koje su za studentskih dana bili članovi raznih društva Katoličkog pokreta. Njihova uloga trebala je biti primjena znanja koje su stekli tijekom studija za unaprjeđenje rada katoličkih organizacija unutar Katoličkog pokreta.

Podijeljenost hrvatske političke scene odrazila se na crkvene krugove. Većina je protagonista podržala raspad Monarhije i uniju sa Srbijom, ali bilo je i drugačijih mišljenja. Uslijed dramatičnih događaja tijekom druge polovice 1917. i cijele 1918., te razlike u mišljenjima postale su otvoreni sukobi koji su zaprijetili jedinstvu cjelokupnog pokreta.

Situacija je eskalirala 1917. u tekstu Pred zoru, objavljenom u Luči od strane jednoga od prvaka HKP-a, Petra Rogulje (Veraja, 1998, 71). ${ }^{10}$ Taj članak predstavlja prvi čin priznanja da postoje velike koncepcijske razlike unutar HKP-a. Uloga koju je imao Đakovački kler, kao idejni nasljednik Strossmayera, vrlo je važna i zanimljiva. On je bio jedan od rijetkih, uz sarajevski kler i isusovce, koji je pozivao na oprez u vezi s jugoslavenskim rješenjem hrvatskog nacionalnog pitanja. ${ }^{11}$ U Đakovu je bilo dosta aktivnih članova Katoličkog pokreta (Ilija Anaković, Andrija Živković, Andrija Spiletak, Zvonimir Marković i dr.). ${ }^{12}$

Posebno je zanimljiva uloga Ilije Anakovića, bliskog suradnika i istomišljenika bl. Ivana Merza. On je u HKP-u bio aktivan od svojih bogoslovskih dana. Ovdje donosim isječak iz korespondencije Ilije Anakovića s Čedomilom Čekadom. U arhivu se nalazi nekoliko pisama. U prvom, datiranom na dan 8. lipnja 1917., Čekada piše da je Pokret zahvatila »nutarnja kriza, a možda, ne daj Bože,

9 Usp. HR-NAZG-KA-20. Interdijacezansko tajništvo kat. muževa, Bratovština Presv. Oltarskog Sakramenta. U Nadbiskupijskom arhivu u Zagrebu nalazimo mnoge nacrte, skice, pravila, statute ili kronotaksu katoličkih udruga i asocijacija. Jedna od njih je i Danica, osnovana 1893. godine.

10 Rogulja je napisao svoj članak kao sintezu tadašnjeg historijata HKP-a. Pokret je podijelio na "nacionaliste" i "integralce". Nacionalisti su prikazani kao tolerantni, oni koji se zalažu za demokratizaciju Crkve, pomirljivost i uniju prema Srbima. Integralci su prikazani kao ultra konzervativci, koji se zalažu za suradnju Crkve i države i oprezan stav prema Srbima. Prvoj grupi je pripadala većina članova HKP-a, društvo Domagoj, svi bogoslovski zborovi osim Sarajevskog, franjevački red. U drugu su spadali frankovci, članovi Seniorata iz Slavonije, isusovci. Zanimljivo, sam biskup Mahnić okarakteriziran je kao "neutralan".

11 Usp. HR-NAĐ-OF-345. Pismena ostavština, vlč. Ilija Anaković. 3. Obrana Orlovskog pokreta, Zbor duhovne mladeži-pisma, isječci iz novina o Katoličkoj akciji. Ilija Anaković bio je jedan od prvaka HKP-a, Katoličke akcije na teritoriju Đakovačke buskupije. Tijekom 20-ih godina bio je povezan s prvacima Hrvatskog orlovskog saveza: Ivanom Merzom, Ivo Protulipcem, Brunom Foretićem i dr. Zastupao je mišljenja koja su bila kompatibilna s Orlovskim savezom u unutarkatoličkim debatama tijekom 20-ih. U 30-ima je postao duhovnik dijacezanskog odbora Velikog križarskog bratstva.

12 Protagonisti HKP-a uglavnom su bili svećenici, iako je bilo i laika. Jedan od njih poznati je Đ akovački odvjetnik Matija Belić, koji je bio prijatelj Ivana Merza još od od vremena kada su zajedno studirali u Parizu. Merz je boravio u njegovoj obiteljskoj kući kada je dolazio u Đakovo. Dva Belićeva sina stupili su u Družbu Isusovu. 
i raskol«. Roguljina je struja optužena za tendenciju »laiciziranja klera i demokratizacije Crkve ${ }^{13}$

Te razmirice nisu ostale samo na privatnoj korespondenciji. Đakovačka je biskupija, u svojem dijacezanskom glasilu iz pera Grgura Galovića objavljivala seriju članaka pod nasovom Vigilantibus Iura, gdje se nedvosmisleno može iščitati različitost u stavovima protagonista HKP-a (Galović, 1917).

Izbijanje rata spriječilo je daljnji razvoj polemika. Mnogi članovi su preminuli, organizacije i udruge su se pasivizirale, a članstvo se smanjilo. Nakon rata krenula je obnova društava u potpuno novom političkom i društvenom kontekstu.

\section{Drugo razdoblje (1918.-1929.)}

Nova je država Kraljevina Srba, Hrvata i Slovenaca od početka bila veliko razočaranje. Ono što se može naći u arhivima ide u prilog tezi da je nova država zauzela izrazito neprijateljski stav prema Katoličkoj crkvi. Represija je odmah postala prevladavajuća politika prema kleru. Stvorena je atmosfera iminentnog državnog udara i pritisaka na episkopat da "preventivno djeluju" u smislu discipliniranja vlastitoga klera, ${ }^{14}$ tj. sprječavanja izražavanja bilo kakve kritike prema postupcima državne vlasti, sve kako bi se osigurala "lojalnost". ${ }^{15}$ To su bili uvjeti i prilike u kojima je počela mukotrpna obnova organizacija i udruga HKP-a.

Kraljevina SHS od početka se pokazala više kao neuspješni eksperiment nego zajednica južnoslavenskih naroda. Ona je nastala kao konglomerat vrlo različitih nacija, vjeroispovijesti, kulturnih tradicija, političkih i gospodarskih suprotnosti. Važno je zabilježiti da je Sveta Stolica od samih početaka gajila veliku rezerviranost prema budućnosti i političkoj održivosti te države (Valente, 2012, 21).

Beogradska elita od samog početka nije pokazivala namjeru da ispoštuje odredbe Krfske deklaracije i da sačuva posebnosti u tako divergentnom po-

13 Usp. HR-NAĐ-OF-345. Pismena ostavština, vlč. Ilija Anaković. 3. Obrana Orlovskog pokreta, Zbor duhovne mladeži-pisma, isječci iz novina o Katoličkoj akciji. Čekada je bio iz izrazito pobožne obitelji. Dva brata su mu bili svećenici, Milivoj i Smiljan Franjo. Potonji je prvo bio skopljanski biskup (1940.-1967.), zatim nadbiskup-koadjutor vrhbosanski (1967.-1970.) te naposljetku nabiskup vrhbosanski (1970.-1976.).

14 Usp. HR-DAOS-1598. Upravna općina Ćepin (1918-1941). Uredba župana županije virovitičke i grada Osijeka br. 591 od 31. prosinca 1919. predstojništvu Kraljevske kotarske oblasti u Osjeku (kut. 28). Riječ je o strogo povjerljivom dokumentu koji je kraljevski župan županije virovitičke i grada Osijeka izdao sebi podređenim administrativnim tijelima, gdje se upozorava na »zlokobno rovarenje rimokatoličkog svećenstva protiv sadašnjeg stanja i narodnog jedinstva«. U prvim godinama postojanja Kraljevine SHS te su optužbe bile uobičajene. Neprestano su se spominjali "nemiri”, "agitacija”, "pokreti stanovništva” itd.

15 Usp. AJ-69. Ministarstvo vera Kraljevine Srba, Hrvata i Slovenaca. 182.286. Obavijest Ministarstva unutrašnjih dela Ministarstvu vera o protudržavnoj agitaciji na području Zagrebačke nadbiskupije od 20. svibnja 1919. Ministarstvo vera taj je dokument poslalo nabiskupu Baueru. Iz obavijesti je evidentno da su sa sadržajem upoznati predsjednik Ministarskog saveta Stojan Protić, ministar unutarnjih poslova Svetozar Pribičević i ministar vera Tugomir Alaupović. Navodi se niz optužbi protiv svećenstva i tvrdi se da isti otvoreno rovare protiv države. Od nadbiskupa se traži da poduzme disciplinske mjere protiv svojega klera. U slučaju da to ne učini prijeti se da će to napraviti državne sudske i policijske vlasti. 
litičko-društvenom krajobrazu nove države. Samo donošenje novog ustava na pravoslavni blagdan Vidovdan bilo je ne samo svojevrsna poruka ostalima, nego je i provedeno bez većine hrvatskih glasova (Goldstein, 2003, 242). Katolički i hrvatski element u Kraljevini Srba, Hrvata i Slovenaca bio je trajno obilježen kao "separatistički", "klerikalan" i onaj koji koči trajnu konsolidaciju nove države.

Glavna institucija koja je bila svojevrsni ideolog takvog shvaćanja naravi južnoslavenske zajednice bila je Srpska pravoslavna crkva, koja je novu državu smatrala proširenom srpskom državom, a samu sebe državnom vjerom. Srpska pravoslavna crkva dijelove nove države koji su bili dio Habsburške Monarhije smatrala je svojevrsnim in partibus infidelibus, te je u tim područjima provodila prozelitizam (Mladineo, 2008). ${ }^{16}$

Kraljevina SHS imala je vrlo slične programe naseljavanja, kolonizacije koje su promijenile etničku i gospodarsku strukturu hrvatskih zemalja. Bila je uz boljševički SSSR jedina europska država koja je provodila agrarnu reformu između dva svjetska rata. Primjerice, kolonizacija na području Đakovačke biskupije, tj. šireg područja Slavonije bila je očita. Zemlju su dobivali razvojačeni pripadnici Srpske kraljevske vojske i politički podobni kadrovi, a dijelovi Slavonije (primjerice područje oko Našica) ${ }^{17}$ i Baranje naseljeni su pravoslavnim stanovništvom.

HKP i njegove organizacije počele su se ponovno organizirati nakon rata. Ubrzo je uspostavljena Jugoslavenska katolička đačka liga 1919., a nakon nje i Hrvatski orlovski savez 1923., koji je odmah privukao u svoje članstvo katoličku mladež i brzo se raširio u hrvatskim zemljama. Hrvatski je episkopat odobrio njegovo djelovanje. Jedan od biskupa koji je Orlove uzimao u zaštitu bio je i Đakovački biskup Antun Akšamović, ${ }^{18}$ koji je utvrdio glavne značajke Orlovskog pokreta ${ }^{19}$ i nove Katoličke akcije.

Đakovačka biskupija postala je jedan od centara Katoličkog pokreta i Katoličke akcije u novoj državi. Protagonisti se nisu bavili samo teološko-filozofskim temama, nego i sve prisutnijim socijalnim pitanjima (Zidarić, 1927, 44-48), ${ }^{20}$ pokušavajući na taj način suzbiti snagu i utjecaj rastuće Komunističke partije.

16 Srpska pravoslavna crkva imala je cijeli program gradnje crkvi na područjima gdje je bilo gotovo u potpunosti katoličko stanovništvo, kao što su bili Mljet, Korčula, Vis, Split i dr. Taj kolonijalni program bio je prepun povijesnih izmišljotina, falsifikata i pseudohistoriografije. U članku se vidi da je beogradski list Vreme (br. 13 dana 13. studenoga1933.) izvještavajući o prelasku manjeg dijela Višana na pravoslavlje tvrdio da su se njihovi preci na Vis doselili iz Smedereva.

17 Usp. AJ-96. Ustanove agrarne reforme Kraljevine Jugoslavije. 2.9. Potvrda o dodjeli nekretnine Simi Beadru od 30. svibnja 1922. U mnoštvu dokumenata nalazimo i taj kojim županijski agrarni ured iz Vukovara dodjeljuje kolonistima zemlju na pustari Grabovac, koja je do tada bila u vlasništvu grofova Eltz.

18 Usp. Arhiv Vrhbosanske nadbiskupje, urudžbeni zapisnik, dokument zaprimljen 26. veljače 1926.

19 Primjerice prvenstvo klera, poslušnost papi i episkopatu, djelovanje sukladno direktivama pape Pija XI. (Markešić, 2002). Papa Pio XI. u svojoj je enciklici Ubi Arcano Dei (23. prosinca 1922.) iznio koncept Katoličke akcije kao »sudjelovanje laikata u apostolatu Crkve pod vodstvom hijerarhije $\ll$.

20 Takvih članaka je bilo na desetine i na zadivljujuće točan i pregledan način pružali su uvid u društveni presjek hrvatskog društva tog vremena. 
Jedan od najvažnijih događaja za vjerski život katolika u novoj državi bili su Euharistijski kongresi. Jedan od njih održan je u Osijeku u kolovozu 1924. (Spiletak, 1924). Taj je događaj bio odraz snage Crkve na tom dijelu hrvatske zemlje. U kongresnim manifestacijama sudjelovao je vjernički puk, katolička pobožna društva i udruge Katoličke akcije. Gotovo cjelokupni episkopat došao je zajedno s nuncijem Pellegrinettijem. Nuncij je tom prilikom pohvalio rad Orlova i prenio im pozdrave od samog Svetog Oca (Glasnik biskupija bosanske i srijemske, 11/ LII, 1924, 87).

Aktivnost Orlova u Đakovačkoj biskupiji bila je redovita i zabilježena na svim razinama života Crkve (Uredništvo, 1927). ${ }^{21}$ Brojnost i snaga orlovskih udruženja privukla je pozornost svih društvenih slojeva te je rasla dok se nije prometnula u vodeću katoličku organizaciju. Ta snaga orlovstva privlačila je pozornost ne samo katoličke javnosti i društvenih grupa naklonjenih Crkvi, nego i neprijatelja. Tu se misli osobito na državnu vlast, koja je smatrala da su Orlovi ideološka suprotnost Sokolskog udruženja. ${ }^{22}$ Borba za duše mladih ljudi bila je nesmiljena i država je činila sve da Orlove što više ograniči u njihovu djelovanju te da uzdigne državno Sokolsko udruženje kao najpoželjniji oblik društvenog angažmana mladeži. Kulminacija tih tendencija bila je zabrana Hrvatskog orlovskog saveza nakon uvođenja Kraljeve diktature.

Prvo desetljeće života Kraljevine SHS bilo je turbulentno. Vodeća hrvatska politička snaga postala je Hrvatska seljačka stranka (HSS) s plebiscitarnom podrškom hrvatskog naroda. Kulminacija društveno-političkih napetosti bio je atentat na hrvatske zastupnike u Beogradu 20. lipnja 1928. godine. Kralj Aleksandar Karađorđević ubrzo nakon toga donio je odluku o suspenziji parlamentarnog života i uveo osobnu diktaturu, a državu preimenovao u Kraljevinu Jugoslaviju. Zabranjena sva "plemenska" udruženja, ${ }^{23}$ a državna je ideologija postalo integralno jugoslavenstvo, koja je negiralo samo postojanje hrvatskog naroda.

Ti događaji utjecali su i na Katolički pokret i Katoličku akciju. Katolička javnost podijelila se u dvije struje. Jedna struja, koju su činili Seniorat, društvo

21 Tu možemo pročitati izvješće o orlovskom tečaju u Đakovu. Takav tip redovitog sastanaka Orlova bio je od krucijalne važnosti za kompaktnost same organizacije, obrazovanje i odgajanje njezinih članova u katoličkom duhu te vidljivi znak njezine snage prema društvu u cjelini.

22 Usp. VA-AA.EE.SS. Serie Jugoslavia IV, Posizione 7, Fascicolo 10, 23r-23v. Izvješće tajnika nuncijature Felicija od 13. lipnja 1922. Tajnik nuncijature u Kraljevini SHS msgr. Felici poslao je 13. lipnja 1922. državnomu tajniku Svete Stolice msgr. Gasparriju dokument u kojem ga informira o razgovorima koje su hrvatski biskupi vodili u Beogradu s ministrom obrazovanja Svetozarom Pribičevićem. Između informacija o stanju oko konkordata, školskog zakona i dr. nalazimo i podatak da je u Beogradu bio ministar vanjskih poslova Čehoslovačke Edvard Beneš koji Pribičeviću savjetuje kako da se ponaša prema Katoličkoj crkvi. Državna vlast u Kraljevini SHS ideje o Sokolskom pokretu u velikoj je mjeri preuzela od čeških liberala.

23 Usp. HR-DAOS-1598. Upravna općina Ćepin (1918-1941). Naredba br. 1071-1029 na dan 17. siječnja 1929. kojom Odelenje javne bezbednosti Ministarstva unutrašnjih dela javlja velikomu županu u Osijeku odluku o zabrani svih vjerskih i plemenskih obilježja (kut. 36). Sva postojeća društva morala su proći obveznu reviziju. Zanimljivo je da srpska zastava nije bila zabranjena jer ju je Srpska pravoslavna crkva proglasila "vjerskim" obilježjem (podatak koji donosi Velimir Deželić ml. na 1138. str. u drugom tomu svojih memoara Kakvi smo bili, koje je objavila Družba Braća Hrvatskoga Zmaja 2011. godine). 
Domagoj i dr., smatrala je da svi katolici trebaju podržavat novoosnovanu Hrvatsku pučku stranku. Druga struja, okupljena oko Orlovskog saveza (Guberina, $1933)^{24}$ zalagala se za depolitiziranu Katoličku akciju (Marković, 1927) uspostavljenu po smjernicama Pija XI., čija je zadaća unutarnja izgradnja katoličke inteligencije koja će poslije preuzeti glavnu ulogu u društvenom životu. Za depolitiziranu Katoličku akciju posebno se zalagao Ivan Merz već kod osnivanja Hrvatskog orlovskog saveza 16. prosinca 1923. godine. Njegovo zalaganje priznali su i hrvatski biskupi na jesenskom zasijedanju Biskupske konferencije 1926. godine.

Polemike i debate koje su se prvo javile u unutrašnjem krugu katoličke inteligencije poput plamena su se proširile na katoličku javnost. Eskalacija javne polemike veže se za godine neposredno prije početka diktature od 1927. do 1929. godine. U tom razdoblju, osim tiskovina i javnih tribina, javljaju se i brojne publikacije u obliku knjižica, ${ }^{25}$ šapirografa (uvezanih tipkanih stranica), letaka itd.

Rasprave su se proširile na mnoge organizacije Katoličke akcije. Na primjeru Đakovačke biskupije nalazimo čitav niz privatne korespondencije u kojoj se ističu povjerljivi i osobni podatci, ${ }^{26}$ iz kojih je vidljivo da je Đakovo u tim raspravama stajalo čvrsto na strani Hrvatskog orlovskog saveza te pokušavalo utjecati na druge sudionike da zauzmu što pomirljiviji ton. Većinom su uspjevali, iako je ta polemika ponekada dobivala neželjene tonove. ${ }^{27}$ Biskup Akšamović i vodstvo organizacija Katoličke akcije u Đakovačkoj biskupiji ponekad se nalazilo i pred sukobima koji su izbijali u samim organizacijama ${ }^{28}$ i za koje se smatralo da su poticani izvana.

Sve katoličke organizacije htjele su dobro svojoj Crkvi i svojemu narodu te treba biti oprezan u isticanju konačnog stava o naravi jedne ili druge struje. Ipak, zbog historijske istine treba napomenuti da povijest nekada ima smisla za ironiju. Jedina politička stranka s hrvatskim predznakom koja je nastavila sudjelovati u

24 Definitivni rascjep u katoličkim redovima bio je tzv. krapanjski puč iz 1925., kada se Orlovski savez odijelio od đačke lige. Seniorat je zbog toga ubrzo isključio iz svojih redova tajnika i predsjedika Orlova, Merza i Protulipca.

25 Usp. HR-NAĐ-OF-345. Pismena ostavština, vlč. Ilija Anaković; 3. Obrana Orlovskog pokreta, Zbor duhovne mladeži-pisma, isječci iz novina o Katoličkoj akciji. Ovdje ću navesti samo dva primjera tih knjižica: Natrag biskupu Mahniću i Orlovstvo i prilike u Hrvatskom katoličkom pokretu.

26 Usp. HR- NAĐ-OF-345. Pismena ostavština, vlč. Ilija Anaković; 13. Sjemenište-zadruga-razno. Osim pojedinačnih pisama, možemo naći i cijele zbirke korespondencije, kao primjerice u tom slučaju, koju je vodio Anaković sa Kniewaldom (pisac prve biografije bl. Ivana Merza). U jednom pismu, iz travnja 1928., raspravlja se o tome kakvu poziciju treba zauzeti prema pisanjima u tisku.

27 Usp. VA-ASV. Archivio Nunziatura Jugoslavia. Serie 15, 257r-258r. Pismo vrbosanskog nadbiskupa Ivana Šarića nunciju Pellegrinttiju od 15. lipnja 1927. U pismu koje je vrhbosanski nadbiskup Šarić poslao nunciju Pelegrinettiju žestoko se napada Seniorat i politika Hrvatske pučke stranke. Iznosi se tvrdnja da je autor jednog članka u tisku, točnije u Seljačkim novinama od 10. lipnja 1927., Stjepan Barić, predsjednik HPS-a. Članak je interpretiran kao napad na biskupa Akšamovića, a bio je naslovljen Vampiri i hijene.

28 Usp. HR-NAĐ-OF-345. Pismena ostavština, vlč. Ilija Anaković; 13. Sjemenište-zadruga-razno. U kolovozu 1927., kako je Ordinarijat u Đakovu izvijestio Kretonić, predsjednik Orlovske općine u Osijeku, izbile su velike polemike oko pitanja smiju li se u članstvo primiti aktivni i bivši članovi Seniorata. 
parlamentarnom životu Kraljevine SHS nakon ubojstva hrvatskih zastupnika bila je Hrvatska pučka stranka s jednim zastupnikom u tadašnjem sazivu parlamenta, Stjepanom Barićem. On je ujedno bio ministar socijalne politike u vladi kojom je predsjedao Anton Korošec i koja je vladala od 27. srpnja 1928. do 6. siječnja 1929. godine.

\section{Treće razdoblje (1929.-1941.)}

Početak posljednjeg desetljeća postojanja Kraljevine Jugoslavije obilježila je diktatura kralja Aleksandra. Njegova politika nije donijela željene rezultate za vlast i već 1931. donesen je Oktroirani ustav, kojim su se pokušali riješiti nagomilani problemi. No, nestabilne političke prilike utjecale su na daljnu radikalizaciju političkog života, što je kulminiralo ubojstvom kralja Aleksandra u Marseillu u listopadu 1934. godine (Pavličević, 2002). Nakon tog događaja situacija se počela smirivati, dobrim dijelom i zbog pogoršanja situacije u Europi. Rezultat je bio sporazum Cvetković-Maček iz kolovoza 1939., kojim je uspostavljena hrvatska autonomija u obliku Banovine Hrvatske.

U odnosima Crkve i države možemo izdvojiti dva velika događaja, jedan s početka, a drugi s kraja desetljeća. Prvi je fenomen Sokolskog pokreta, koji je vlast promovirala kao obvezan za veliku većinu mladeži u državi. To je naišlo na veliki otpor u Crkvi (Sršan, 2011, 150) ${ }^{29}$ i označilo po prvi put jasno protivljenje cjelokupnog episkopata. Takav rezolutan stav hrvatskog episkopata prouzrokovao je konsternaciju državne vlasti, koja je ubrzo čak pripremila zakonski prijedlog o izgonu isusovaca kao znak odmazde (Glasnik biskupija bosanske i srijemske, LXI/4, 1933, 20-21).

Protagonisti HKP-a pratili su ta događanja i pokušavali naći adekvatan odgovor na njih. Anaković je u svojem dnevniku u zapisu s nadnevkom 24. siječnja 1933. zabilježio da je u tijeku velika propaganda za prijelaz mladeži iz katoličkih udruga u sokolstvo. ${ }^{30}$ Taj fenomen bio je prisutan i u drugim hrvatskim krajevima, a njegovi tragovi mogu se naći u našim biskupskim arhivima.

Drugi veliki sukob bio je pitanje konkordata. Država je odugovlačila s donošenjem konkordata od samog nastanka. Kada je konačno potpisan, Srpska pravoslavna crkva povela je oštru kampanju za njegovo povlačenje, što je kulminiralo tzv. Krvavom litijom u srpnju 1937. godine. ${ }^{31}$ Država je popustila pred pritiscima Pravoslavne crkve te na kraju povukla konkordat iz parlamentarne procedure

29 Autor donosi presliku okružnice Biskupske konferencije Jugoslavije 31. prosinca 1922. namijenjene svećenstvu i vjernicima o sokolskom duhu Tyršova sustava.

30 Usp. HR-NAĐ-OF-345. Pismena ostavština, vlč. Ilija Anaković, 12. Društva, dnevnik, isječci iz novina, fotografije, razglednice.

31 Usp. AT-OeStA/AVA Kultus NK Kath Akten 892.2. Signatur 65: Jugoslawien. Dokument br. 5930 od 21. siječnja 1937., dopis austrijskog veleposlanstva u Beogradu ministarstvu vanjskih poslova. Pitanje konkordata je i internacionalizirano, kao što nam govori taj dokument austrijskog veleposlanstva, u kojem se govori da se čeka "neuobičajeno" dugo vrijeme za ratifikaciju konkordata. 
(Mužić, 1978, 198). ${ }^{32}$ Takav šokantan razvoj događaja uvjetovao je da se kao kompenzacija za neratificiranje konkordata usvoji Uredba o verama i međuverskim odnosima, ${ }^{33}$ čiji je koautor s katoličke strane bio Franjo Herman, svećenik Đakovačke biskupije.

O napetosti situacije oko konkordata, koja se prelila na cijelu državu, svjedoči i pismo koje je poznati Đakovački odvjetnik Ivan Ribar uputio uredniku Glasnika biskupije Đakovačke i srijemske Zvonimiru Markoviću. ${ }^{34}$ Optužio je Crkvu i njezine predstavnike da su ruka rimske politike i oruđe u rukama političkog klerikalizma.

Nakon prisilnog ukinuća Hrvatskog orlovskog saveza, Crkva je kroz pobožno društvo Apostolat molitve uspjela zadržati mladež kroz osnivanje Velikog križarskog bratstva (Krišto, 2002), ${ }^{35}$ a poslije i Velikog križarskog sestrinstva. Križari su se raširili po svim hrvatskim biskupijama uz potporu episkopata (biskupi Šarić, Mileta i Akšamović) i katoličke javnosti, iako je ponekada znalo biti manjih poteškoća (Križarska straža, 5/6, 1934, 168). ${ }^{36}$ Križarsko je bratstvo primjerice u Slavoniji i Đakovačkoj biskupiji gotovo u potpunosti preuzelo članstvo svojih prethodnika Orlova te postalo najjača snaga u javnom djelovanju Katoličke crkve (Crnčan i Dević, 2003, 282). ${ }^{37}$ Procjenjuje se da je u jednom trenutku, oko 1938. bilo više od 30.000 članova Križarskog bratstva.

Približavanje Drugog svjetskog rata nije usporilo rad Crkve i njezinih organizacija, nego je u tom vremenu Katolička akcija bila čak i najaktivnija. Jedna od posljednjih velikih aktivnosti pred rat bila je organiziranje socijalnog tjedna $\mathrm{i}$ pripreme za jubilarnu hrvatsku godinu 1940.-1941. ${ }^{38}$ i proslavu 1300 godina veza Hrvata sa Petrovom Stolicom.

32 Kakve su sve silnice bile protiv ratifikacije konkorata govori i svjedočanstvo nuncija Pellegrinettija da Anton Korošec, u svim godinama koje je proveo u Beogradu (1922.-1937.), nikada nije prešao prag apostolske nuncijature.

33 Usp. AJ-334. Ministarstvo inostranih poslova Kraljevine Jugoslavije. 27.66.271/361. Obavijest ministra pravde ministru vanjskih poslova od 15. kolovoza 1940.

34 Usp. HR-NAĐ-OF-405. Pismena ostavština, vlč. Zvonimir Marković, 1. Dekreti, dokumenti, dopisivanje, propovijedi za bogoslove. Pismo je datirano na dan 10. ožujka 1937. godine.

35 Nadbiskup Bauer odobrio je pravila Križara 13. siječnja 1930. godine.

36 Križari su se morali braniti od napada političke provenijencije jer su bili optuživani da su u biti političko krilo HSS-a. Protivnici su opravdanje za takav stav nalazili u izrazito pozitivnim komentarima o Križarima koje je pisao tadašnji vođa HSS-a Vlatko Maček.

37 Autori donose izvješće o Križarima u slavonskom mjestu Viljevo. Biskup Akšamović potvrdio je osnivanje Križarskog bratstva svojim pismom od 21. rujna 1936. godine. Tragovi orlovskih i križarskih društava nalaze se diljem biskupije.

38 Usp. HR-NAZG-KA-20. Interdijacezansko tajništvo kat. muževa, Bratovština Presv. Oltarskog Sakramenta. Imenovanje dijacezanskog odbora u Đakovu za proslavu Hrvatskog jubilja 1941., dopis od 12. siječnja 1940., br. 80. Ta inicijativa bila je prihvaćena u cijeloj Crkvi u Hrvata. Ordinarijat u Đakovu odlukom biskupa Akšamovića imenovao je Odbor za proslavu hrvatskog jubileja kojim je predsjedao Zvonimir Marković, a članovi su bili profesori na bogosloviji u Đakovu Pero Ivanišić, Ivo Rogić i drugi. 


\section{Zaključak}

Hrvatski katolički pokret (1903.-1945.) prvenstveno je značio organizirano javno djelovanje katoličkih laika i katoličkih udruga. Pod vodstvom crkvene hijerarhije, pretežito sastavljen od katoličkih laika, bio je snaga s kojom se Crkva suočila s izazovima koji su ju čekali na početku 20. stoljeća. Društvene okolnosti dramatično su se izmijenile u tom razdoblju zbog epohalnih političko-državnih promjena.

Prvi dio u razdoblju od 1900. do 1918. obilježen je početcima i izvorima samog Pokreta. Drugi dio u razdoblju od 1918. do 1929. sbavio se prvim desetljećem postojanja južnoslavenske države. Treće razdoblje od 1929. do 1941. pratio je najvažnija zbivanja prije početka Drugog svjetskog rata.

Tijekom tih desetljeća postojale su razne ideje i strategije u njegovu djelovanju, ali sve su imale jedan zajednički cilj: obranu i širenje Kristovih načela i nauka Crkve u osobnom životu svakog pojedinca i na širem društvenom planu.

Udruženja i organizacije Hrvatskog katoličkog pokreta te predanost njegovih članova bili su jedan od najvažnijih čimbenika koji su Crkvi u Hrvata omogućili da opstane u najtežem razdoblju svoje povijesti: Drugom svjetskom ratu (1941.1945.) i u vremenu komunističkog režima sve do demokratskih promjena 1990. godine.

\section{Arhivsko gradivo}

\section{AJ Arhiv Jugoslavije}

AJ-69. Ministarstvo vera Kraljevine Srba, Hrvata i Slovenaca

AJ-96. Ustanove agrarne reforme Kraljevine Jugoslavije

AJ-334. Ministarstvo inostranih poslova Kraljevine Jugoslavije

Arhiv Vrhbosanske nadbiskupije

Urudžbeni zapisnik 1926.

HR-DAOS Državni Arhiv u Osijeku

HR-DAOS-1598. Upravna općina Ćepin (1918-1941)

HR-HDA Hrvatski državni arhiv

HR-HDA-71. Carsko kraljevsko Ministarstvo bogoštovlja i nastave. Hrvatsko-slavonski spisi. 1848-1861.

HR-NAĐ Nadbiskupijski Arhiv u Đakovu

HR-NAĐ-OF-345. Pismena ostavština, vlč. Ilija Anaković

HR-NAĐ-OF-405. Pismena ostavština, vlč. Zvonimir Marković 
HR-NAZG Nadbiskupijski arhiv u Zagrebu

HR-NAZG-KA-20. Interdijacezansko tajništvo kat. muževa, Bratovština Presv. Oltarskog Sakramenta.

AT-OeStA/AVA Österreichischen Staatsarchiv / Allgemeines Verwaltungsarchiv

AT-OeStA/AVA Kultus NK Kath Akten

AT-OeStA/HHStA Österreichischen Staatsarchiv / Haus-, Hof-und Staatsarchiv

AT-Oesta/HHStA PA XI 260. V/5: Slavische Liturgie

VA-AES Archivio della Congregazione degli Affari Ecclesiastici Straordinari

VA-AA.EE.SS. Serie Jugoslavia IV

VA-ASV Archivio Segreto Vaticano

VA-ASV-Archivio Nunziatura Jugoslavia

\section{Literatura:}

Bilandžić, Dušan (1999). Hrvatska moderna povijest. Zagreb: Golden Marketing.

Boban, Branka (2001). Odnos hrvatske političke elite prema Svibanjskoj deklaraciji Jugoslavenskog kluba od 30. svibnja 1917. U: Dušan Gauber, Igor Graovac i Olivera Milosavljević (ur.), Dijalog povjesničara-istoričara (str. 309-325). Zagreb: Zaklada Friedrich Neumann.

Crnčan, Marko; Dević, Antun (2003). Župa Viljevo. Viljevo: Vlastita naknada.

Galović, Grgur (1917). Vigilantibus Iura. Glasnik biskupija bosanske i srijemske, 45(13), 99-103.

Goldstein, Ivo (2003). Hrvatska povijest. Zagreb: Novi Liber.

Gottsmann, Andreas (2010). Rom und die Nationalen Katholizismen in der Donaumonarchie: Romisher Universalismus, habsburgische Reichspolitik und nationale Identitäten 1878-1914. Beč: Verlag der Österreichischen Akademie der Wissenschaften.

Guberina, Ivo (1933). Zelena knjiga. Zagreb: vlastita naknada.

Korenić, Stjepan (1900). Prvi hrvatski katolički sastanak obdržavan u Zagrebu dne 3., 4. i 5. rujna godine 1900. Zagreb: C. Albrecht.

Krišto, Jure (2002). Hrvatski katolički pokret od šestosiječanjske diktature do početka Drugoga svjetskog rata (1929-1941). U: Zlatko Matijević (ur.), Hrvatski katolički pokret: Zbornik radova s Međunarodnoga znanstvenog skupa održanog u Zagrebu i Krku od 29. do 31. ožujka 2001. (str. 759-789). Zagreb: Kršćanska Sadašnjost

Krišto, Jure (2004). Hrvatski katolički pokret: 1903-1945. Zagreb: Glas Koncila.

Markešić, Ivan (2002). Katolički pokreti: Europski kontekst. U: Zlatko Matijević (ur.), Hrvatski katolički pokret: Zbornik radova s Medunarodnoga znanstvenog skupa održanog u Zagrebu i Krku od 29. do 31. ožujka 2001. (str. 57-76) Zagreb: Kršćanska sadašnjost.

Marković, Zvonimir (1927). Ideologija Katoličke Akcije. Đakovo: Nadbiskupska Tiskara. 
Mladineo, Goran (2008). Primjer vjerskog pragmatizma: Prijelaz viških težaka na pravoslavnu vjeru između dva svjetska rata. Radovi: Zavod za hrvatsku povijest, 40, 231-248.

Mužić, Ivan (1978). Katolička crkva u Kraljevini Jugoslaviji: Politički i pravni aspekti konkordata između Svete Stolice i Kraljevine Jugoslavije. Split: Crkva u svijetu.

Pavličević, Dragutin (2002). Povijest Hrvatske: Treće dopunjeno izdanje. Zagreb: Naklada Pavičić.

Radić, Ignacije (1940). Dr. Antun Mahnić, biskup Krčki. Požega: Grafika.

Spiletak, Andrija (1924). Spomen-knjiga Euharistijskog kongresa u Osijeku 15.-17. kolovoza 1924. Osijek: Prva hrvatska dionička tiskara.

Sršan, Stjepan (2012). Spomenica rkt. župe Preslavnog imena Marijina Donji grad Osijek: 1887.-1974. godine. Osijek: Državni arhiv u Osijeku.

Suppan, Arnold (1980). Die Kroaten. U: Adam Wandruszka, Peter Urbanitsch (ur.), Die Habsburgermonarchie 1848-1818: Band III: Die Völker des Reiches. (str. 626-733). Beč: Verlag der Österreichischen Akademie der Wissenschaften.

Uredništvo (1927). Orlovski tečaj u Đakovu. Orlovska straža, 4, 124.

Valente, Massimiliano (2012). Diplomazia Pontificia e Regno dei Serbi, Croati e Sloveni (1918-1929). Split: Filozofski Fakultet u Splitu.

Veraja, Fabijan (1998). Ivan Merz: Pioniere dell' Azione Cattolica. Città del Vaticano: Libreria Editrice Vaticana.

Zidarić, Josip (1927). Socijalne i staleške prilike u Hrvata. Luč, 2(23), 44-48.

Znidarčić, Lav (2002). Hrvatski katolički pokret i Katolička akcija (1910.-1945.). U: Zlatko Matijević (ur.), Hrvatski katolički pokret: Zbornik radova s Međunarodnoga znanstvenog skupa održanog u Zagrebu i Krku od 29. do 31. ožujka 2001. (str. 629-639). Zagreb: Kršćanska sadašnjost.

The Croatian Catholic Movement at the Beginning of the 20th Century

Ivan Zubac*

\section{Summary}

The article outlines the origins and development of the organisation of the Croatian Catholic Movement and of Catholic Action, one of the most significant events in the particular Church in Croatia at the beginning of the 20th century. The article consists of three parts each of which corresponds to the most important occurrences within that particular period. These are the creation of a new South-Slavic state, the period of pseudo-parliamentarism in the 1920's and the final decade of the life of the Kingdom of Serbs, Croats and Slovenes/the Kingdom of Yugoslavia.

Key words: Croatian Catholic Movement, Catholic Action, Croatian Eagles' Association, Kingdom of Serbs, Croats and Slovenes/Kingdom of Yugoslavia

* Ivan Zubac, Doctorand at the Faculty of History and Cultural Heritage of the Church, Pontifical Gregorian University, Piazza della Pilotta, 4, 00187 Roma, Italia. E-mail: ivanzubac@gmail.com 